\title{
Decreasing incidence of coeliac disease
}

\author{
F M STEVENS, B EGAN-MITCHELL, E CRYAN, C F MCCARTHY, AND B MCNICHOLL \\ Departments of Paediatrics and Medicine, Regional Hospital and University College, County Galway, Ireland
}

SUMmARY Between 1960 and 1974 the incidence of coeliac disease in children under 12 years in County Galway remained fairly constant, but since 1975 it has fallen by $62 \%$ and the lowered incidence seems well established. The number of those who were breast fed and the age at which first gluten feeding took place during the 22 years both increased significantly and from the mid-70s total protein content and osmolarity of proprietary cow's milk formulas were reduced. All three factors may be relevant. A negative correlation with the incidence of gastroenteritis was found.

Reports from other centres ${ }^{1-3}$ and our experience led us to review the incidence of coeliac disease in County Galway over a 22 year period. The incidence of the first 11 years of this period, which we reported in $1973,{ }^{5}$ was then the highest known. This area has the highest recorded prevalence of human leucocyte antigens (HLA) B8 and DR3, ${ }^{\circ}$ and this county has favourable features for a study of this kind as the population has remained fairly stable.

Until 1979 ours was the only centre in County Galway that performed intestinal biopsy examinations (since then we have been informed of cases diagnosed in children in another hospital undertaking such examinations). These factors, together with the presence of departments with a specific interest in the disease, have probably resulted in our area having as high an ascertainment as any other area where incidence has been studied.

\section{Patients and methods}

Intestinal biopsy specimens were taken with Crosby or Watson capsules from the distal duodenum or proximal jejunum under fluoroscopic control. All appraisals of dissecting microscope and histological features in children were made by the same person (BM) throughout the study and classified as described previously. ${ }^{7}$ All biopsy specimens were classified as grade II or III. Under the dissecting microscope the mucosa was either flat or convoluted; histological section showed either absence of villi or low villous projections, with elongation of crypts, reduction in height of enterocytes, increased ratio of lymphocytes to enterocytes in the eplthelium, and increased cellularity in the lamina propria, consisting mainly of plasma cells.

One hundred and three children under 12 years were diagnosed during 22 years, 54 of whom were the subject of our previous study. ${ }^{5}$ The rate of incidence for each period of 11 years was struck two years after the end of that period to make them comparable. For example, only children born between January 1960 and the end of December 1970, who had presented with coeliac disease before the end of 1972, were included in that period. In Table 1 the 22 years have been divided into four equal periods. Gluten challenge to confirm the diagnosis by inducing mucosal relapse was carried out in 13 children, all of whom relapsed and who form part of a separate report. ${ }^{8}$ In 18 children the persistence of gluten intolerance was shown by incomplete mucosal recovery due to poor compliance with the diet. Gluten challenge was not carried out on the remainder as we found that mucosal relapse occurred in 47 of 50 children given gluten challenges, having excluded those with acute enteritis, cow's milk intolerance, and immune deficiency (other than selective IgA deficiency). ${ }^{8}$

A comparison was made between the annual admission to our centre of children under 12 with gastroenteritis during the 22 years and cases with coeliac disease presenting in the same years (irrespective of their birth years). This is the only centre in the county with a designated gastroenteritis and isolation unit, and we used admissions rather than notification of gastroenteritis as the latter refers only to specific bacterial pathogens and is incomplete.

\section{Results}

Table 1 shows total births for County Galway and cases of coeliac disease according to their year of birth and expressed as a ratio of total births and per 
Table 1 Total births and No of cases of coeliac disease according to their year of birth as ratio of total births and per 1000 births in County Galway over a 22 year period (1960-81), divided into 5.5 year quarters

\begin{tabular}{|c|c|c|c|c|}
\hline & \multicolumn{4}{|l|}{ Period of birth } \\
\hline & $\begin{array}{l}1 \text { Jan } 1960- \\
30 \text { June } 1965\end{array}$ & $\begin{array}{l}1 \mathrm{July} 1965- \\
31 \text { Dec } 1970\end{array}$ & $\begin{array}{l}\text { I Jan } 1971- \\
30 \text { June } 1976\end{array}$ & $\begin{array}{l}\text { I July } 1976 \\
31 \text { Dec } 1981\end{array}$ \\
\hline Total births & 16313 & 15874 & 18005 & 19271 \\
\hline \multicolumn{5}{|l|}{ Cases of coeliac disease: } \\
\hline As ratio of total births & $1: 604$ & $1: 590$ & $1: 514$ & $1: 1376$ \\
\hline Per 1000 live births & $1 \cdot 65$ & $1 \cdot 69$ & 1.94 & $0 \cdot 73$ \\
\hline
\end{tabular}

1000 births, in four successive periods of $5 \cdot 5$ years. The incidence of coeliac disease for the first three periods was similar but fell by $62 \%$ during the last quarter. The fall began in 1975 and contrasted with a rise in birth rate, which was slightly in excess of the rate of growth of the population. ${ }^{*}$ These figures also contrasted with those for the prevalence of adult coeliac disease, ${ }^{*}$ which have continued to rise since the setting up of a department of gastroenterology in 1969. Admissions for gastroenteritis rose slightly during the fourth period of study, whereas cases of childhood coeliac disease decreased. ${ }^{*}$

Changes in infant feeding practices. Before the mid70 s, most artificially fed Irish infants received formulas based on largely unmodified cow's milk, and some were still receiving foods based on liquid cow's milk; relatively few were receiving formulas based on 'humanised' cow's milk. By 1978," all infant formulas were modified in a similar manner, the major changes being a reduction in total protein and electrolyte content to concentrations similar to those in breast milk. There was also a trend to replace a major proportion of butterfat by vegetable fats. These changes were concurrent with those in the United Kingdom. Even though some formulas used high proportions of whey protein and thus of $\beta$ lactoglobulin compared with casein and were potentially more antigenic, it is thought that processing reduces antigenicity. ${ }^{10}$ so that from the mid-70s Irish babies received feeds that were probably less antigenic than hitherto and that were closer in osmolarity to breast milk, as well as having less butterfat.

No national or county records for breast and gluten feeding are available for the earlier part of the period under review, so one of us (BM) reviewed some thousands of personal records of patients, referred in this area, extracting from them all those that had valid information concerning breast and gluten feeding.

\footnotetext{
${ }^{*}$ Data available on request
}

Table 2 shows that there were significant increases in those breast feeding for more than a month (from $12 \%$ to $28 \%$ ) and in the mean age of gluten introduction (from 2.3 to 4.2 months) in the first compared with the fourth 5.5 year period. Mothers breast fed for somewhat longer in the last quarter ( 3.1 months) compared with the first $(2.6$ months). The social groups in this review had a bias towards the more affluent and therefore probably towards a greater tendency to breast feed and to be more conservative about the introduction of gluten, but they were similar in both periods. We believe that these figures were representative of a fairly broad range of the county's predominantly rural population. A survey of feeding practices in this area in February and March 1986 by area medical officers at our request confirmed the trends in the personal review, in that $34.5 \%$ of 665 infants of all social groups seen at 7 months for developmental screening were breast fed for more than one month, and the mean age of gluten introduction in 670 infants was 3.8 months.

As far as the relation of breast and gluten feeding to the incidence of coeliac disease was concerned, we sought information from a continuing study of a cohort of 52 patients from 1960 to 1970 in whom coeliac disease was confirmed by gluten challenge; we were able to find some controls comparable in age and sex from hospital records of the same period. Four of 20 children with coeliac disease were breast fed for over a month compared with nine of

Table 2 Personal records of breast and gluten feeding for the first and last 5.5 year periods

\begin{tabular}{lll}
\hline & $\begin{array}{l}\text { Breast feeding } \\
\text { for over one } \\
\text { month }(\%)\end{array}$ & $\begin{array}{l}\text { Mean age at } \\
\text { which gluten } \\
\text { started (months) }\end{array}$ \\
\hline 1 Jan $196(1-30$ June 1965 & $12 \cdot 0 \quad(\mathrm{n}=319)$ & $2 \cdot 3 \quad(\mathrm{n}=130)$ \\
1 July $1976-31$ Dec 1981 & $24 \cdot 0)^{*}(\mathrm{n}=16.3)$ & $4 \cdot 2^{*} \quad(\mathrm{n}=45)$ \\
\hline${ }^{*}$ Both significant, p<0.(0)1. & & \\
$\mathrm{n}=$ No of infant records. & &
\end{tabular}


40 controls. Fifteen $(63 \%)$ of 24 children with coeliac disease were first fed gluten before 2 months compared with $20(54 \%)$ of 37 controls. The differences were not significant.

\section{Discussion}

During the period under review, as there has been little change in the genetic background in County Galway, with its high prevalence of HLA-B8 and HLA-D3, we believe that the declining incidence of childhood coeliac disease must be due to environmental factors. As there was a negative correlation with gastroenteritis during the last quarter when incidence of coeliac disease decreased we assume that changes in infant feeding were the major causes of the decreased incidence.

A retrospective study in three Italian cities argued that in families with a child who had coeliac disease siblings who were artificially fed were four times more likely to have the disease than those who were breast fed for more than a month. ${ }^{11}$ Our smaller retrospective analysis did not show a similar trend. We have shown that breast feeding was over twice as prevalent in the last compared with the first quarter of the 22 years of study and that the mean time of gluten introduction was almost doubled. In addition, infant formulas were modified for almost all of the last quarter.

As the newborn infant matures his immunological efficiency improves; the gut becomes less permeable to macromolecules ${ }^{12}$ and there is an increase in both the number of IgA plasma cells in the lamina propria and the quantity of secretory $\operatorname{IgA}$ in the glycocalyx and lumen. ${ }^{13}{ }^{14}$ Breast feeding provides an optimal nutritional and immunological state in the gut, providing intraluminal $\operatorname{IgA}$ as well as other anti-bacterial and trophic factors. ${ }^{15}$

A role for $\operatorname{IgA}$ in the prevention of coeliac disease is supported by our finding of selective IgA deficiency in 11 of 354 patients with the disease; this represents a 15-fold increase in the incidence of coeliac disease in these patients compared with that in the general population. ${ }^{16}$ The increased concentrations of $\operatorname{IgA}$ expected in the gut with increasing age ${ }^{14}$ may render it less susceptible to a pathological reaction to gluten even at 4 as opposed to 2 months. The high concentrations of proteins and solutes in the previously unmodified cow's milk formulas may have increased the susceptibility of the gut to abnormal interaction with gluten. We cannot identify any one factor responsible for the decreasing incidence of coeliac disease but believe that major factors have been the increase in both the number of mothers who breast fed and the age of first gluten feeding together with the lowered antigenicity and osmolarity of infant formulas.

We have no evidence based on intestinal biopsy examination for the incidence of coeliac disease in the county before 1960 . In the earlier years of the century breast feeding would probably have been more prevalent and wheat feeding introduced at a later stage. If this were the case the incidence of coeliac disease may have been such that the high incidences from 1960 to 1976 represented a response to the prevailing fashion of more artificial feeding including early wheat feeding, and the present lower incidence represents a return to a basic level. We have no evidence so far that the decreased incidence reflects merely a postponement of the expression of the disease as we have not yet seen further cases of coeliac disease born between 1976 and 1981 .

Since our original report of a high incidence, ${ }^{5}$ additional cases of coeliac disease have been identified in the cohort born between 1960 and 1971, causing a rise in incidence from $1 / 597$ to $1 / 450$. In that publication we estimated that the incidence of the disease in the total population of County Galway may have been as high as $1 / 300$, that figure being derived from the incidence in children and the mean annual rate of detection in adults, neither symptomatic nor diagnosed in childhood. By the time this cohort reaches old age an incidence of 1/300 may have become fact rather than speculation.

We acknowledge the help of our colleagues, medical and nursing, Dr Kevin Connolly for details of children diagnosed in Portiuncula Hospital, Ballinasloe, A E Mettler of Farley Health Products Ltd for information on cow's milk formulas, officials of the Central Statistics Office, Dr E McHale for coordinating the survey of infant feeding by area medical officers, and Dr J Colaco for help with statistics. The studies were aided by the Western Health Board, the Medical Research Council of Ireland, and the Wellcome Trust.

\section{References}

' Littlewood JM, Crollick AJ, Richards DG. Childhood cocliac disease is disappearing. Lancet 1980;ii: 1359 .

2 Dossetor JFBB, Gibson AAM, McNeish AS. A recent reduction in the incidence of childhood cocliac disease in the west of Scotland. In: McDonnell RB, ed. The genetics of coeliac disease. Lancaster: MTP Press, 1981.

3 Langman MJS, McDonnell TH, Spiegelhalter DJ, McDonnell RB. Changing patterns of coeliac disease frequency: an analysis of Coeliac Society membership records. Gut 1985;26:175-8.

${ }^{4}$ Stevens FM, Egan-Mitchell B, McCarthy CF, McNicholl B. Factors in the epidemiology of coeliac disease in the west of Ircland. In: McDonnell RB, ed. The genetics of coeliac disease. Lancaster: MTP Press, 1981.

5 Mylotte M, Egan-Mitchell B, McCarthy CF, McNicholl B. Incidence of cocliac disease in the west of Ireland. $\mathrm{Br}$ Med J 1973;i:703-5.

- McKenna R, Stevens FM, McNicholl B, Scholz S. Albert E, McCarthy CF. Family and population studies of HLA and coeliac disease in the west of Ireland. Tissue Antigens 1983;22:175-81 
468 Stevens, Egan-Mitchell, Cryan, McCarthy, and McNicholl

${ }^{7}$ Egan B, McNicholl B. Jejunal biopsy in celiac disease. Clin Pediatr 1968;7:544-52.

${ }^{8}$ McNicholl B, Egan-Mitchell B. Fottrell PF. Variability of gluten tolerance in treated childhood coeliac disease. Gut 1979;20:126-32.

9 Mettler AE. Infant formula. Acta Paediatr Scand [Suppl] 1982;299:58-76.

10 MacLaughlan P, Anderson KJ, Widdowson EM, Coombs RRA. Effects of heat on the anaphylactic-sensitizing capacity of cows milk, goats milk, and various infant formulae fed to guinea-pigs. Arch Dis Child 1981;56:156-71.

"Auricchio S, Follo D, de Ritis G, et al. Does breast feeding protect against the development of clinical symptoms of coeliac disease in children. J Pediatr Gastroenterol Nutr 1983;2:428-33.

12 Udall J, Walker WA. The physiologic and pathologic basis for the transport of macromolecules across the intestinal tract. J Pediatr Gastroenterol Nutr 1982;1:295-301.
${ }^{13}$ Perkkio M, Savilhati E. Time of appearance of immunoglobulin containing cells in the mucosa of the neonatal intestine. Pediatr Res 1980;14:953-5.

14 Tomasi TB. The development of the secretory system. In: Olster AG, Weiss L, Prentice-Hall, Englewood NJ, eds. The immune system of secretions. 1975:41-56.

15 Prittard WB. Breast milk immunology. Am J Dis Child 1979;133:83-7.

${ }^{16}$ Bachman R. Studies on the serum $\gamma$ A-globulin level. III: The frequency of A- $\gamma$ A-globulinaemia. Scand J Clin Lab Invest 1965;17:316-20.

Correspondence to Professor B McNicholl, Department of Paediatrics, Regional Hospital, University College Galway, County Galway, Ireland.

Received 11 December 1986 